\title{
Potential neuroprotective of trans-resveratrol a promising agent tempeh and soybean seed coats-derived against beta- amyloid neurotoxicity on primary culture of nerve cells induced by 2-methoxyethanol
}

\author{
Potencial neuroprotetor do agente trans-resveratrol em cascas de sementes de soja \\ e tempê derivadas da neurotoxicidade beta-amiloide na cultura primária de células \\ nervosas induzidas pelo 2-metoxietanol
}

\author{
Y. Irnidayantia,b* (iD, D. R. Sutiono ${ }^{\mathrm{b}}$ (iD, N. Ibrahim ${ }^{\mathrm{c}}$ (iD, P. H. Wisnuwardhanid ${ }^{\mathrm{d}}$ (iD and A. Santoso ${ }^{\mathrm{d}}$ (iD) \\ aUniversitas Negeri Jakarta, Faculty of Mathematics and Science, Department of Animal Development, Biology, Jakarta, Indonesia \\ bJakarta State University, Faculty of Mathematics and Natural Sciences, Research Group of Biology, Jakarta, Indonesia \\ 'Universitas Indonesia, Faculty of Medicine, Jakarta, Indonesia \\ dIndonesian Institute of Sciences - LIPI, Biotechnology, Bogor, Indonesia
}

\begin{abstract}
Resveratrol, a natural polyphenol found in tempeh, has not been investigated especially in vitro as a neuroprotective agent against 2-methoxyethanol (2-ME)-induced beta-amyloid cytotoxicity. Beta amyloid peptides (A $\beta$ ) could initiate neurotoxic events and neuron-inflammatory response via microglial activation. However, it remains unknown whether the neurotoxic effect of beta-amyloid and/or associated with the potential of 2-ME to induce neurotoxic effects on primary culture of nerve cells induced by 2-ME. This study investigated potential neuroprotective of trans-resveratrol a promising agent tempeh and soybean seed coats-derived against betaamyloid cytotoxicity on primary culture of nerve cells induced by 2-methoxyethanol. Biotium and MTT assays were used to analyze neurons, which were isolated from the cerebral cortex of fetal mice at gestation day 19 (GD-19). A standard solution of 2-methoxyethanol was dosed at $10 \mu \mathrm{L}$. The cultured cells were randomly divided into the following groups: (1) 2-ME group + resveratrol standard, (2) 2-ME group + resveratrol isolated from tempeh, (3) 2-ME group + resveratrol isolated from soybean seed coats, and (4) the control group, without the addition of either 2-ME or resveratrol. Exposure of the primary cortical neuron cells to beta-amyloid monoclonal antibody pre-incubated for $24 \mathrm{~h}$ with $10 \mu \mathrm{L}$ of $4.2 \mu \mathrm{g} / \mathrm{mL}$ resveratrol and $7.5 \mathrm{mmol} / \mathrm{l} 2$-methoxy-ethanol additions. Here, we report that the addition of 2-ME and resveratrol (standard and isolated from tempeh) of cell culture at concentrations of $1.4,2.8$ and $4.2 \mu \mathrm{g} / \mathrm{mL}$ showed that the majority of neurons grew well. In contrast, after exposure to 2-ME and Beta-amyloid, showed that glial activated. These findings demonstrate a role for resveratrol in neuroprotective-neurorescuing action.
\end{abstract}

Keywords: 2-methoxyethanol, resveratrol, neurotoxic, neuroprotective, neurorescuing.

\begin{abstract}
Resumo
O resveratrol, um polifenol natural encontrado em tempê, não foi investigado apenas in vitro como agente neuroprotetor contra a citotoxicidade beta-amiloide induzida por 2-metoxietanol (2-ME). Os peptídeos betaamiloides $(A \beta)$ podem iniciar eventos neurotóxicos e resposta inflamatória dos neurônios via ativação microglial. No entanto, permanece desconhecido se o efeito neurotóxico do peptídeo beta-amiloide associado ao potencial do 2-ME causa efeitos neurotóxicos na cultura primária de células nervosas induzidas pelo 2-ME. Este estudo investigou o potencial neuroprotetor do agente trans-resveratrol em cascas de sementes de soja e tempê derivadas da citotoxicidade beta-amiloide na cultura primária de células nervosas induzidas pelo 2-metoxietanol. Ensaios de biotium e MTT foram utilizados para analisar os neurônios isolados do córtex cerebral de camundongos fetais no dia da gestação 19 (GD-19). As células cultivadas foram divididas aleatoriamente nos seguintes grupos: (1) grupo 2-ME + padrão de resveratrol; (2) grupo 2-ME + resveratrol isolado de tempê; (3) grupo 2-ME + resveratrol isolado de cascas de sementes de soja; e (4) grupo controle, sem a adição de 2-ME ou resveratrol. Houve exposição das células primárias dos neurônios corticais ao anticorpo monoclonal beta-amiloide pré-incubado por 24 horas, com $10 \mu \mathrm{L}$ de $4,2 \mu \mathrm{g} / \mathrm{mL}$ de resveratrol, e adições de 7,5 mmol/l de 2-metoxietanol. A adição de 2-ME e resveratrol (padrão e isolado do tempê) da cultura de células nas concentrações de 1,4, 2,8 e 4,2 $\mu \mathrm{g} / \mathrm{mL}$ mostrou que a maioria
\end{abstract}

*e-mail: yirnidayanti@unj.ac.id; irnidayanti@gmail.com

Received: March 30, 2020 - Accepted: June 16, 2020 
dos neurônios cresceu bem. Por outro lado, após a exposição ao 2-ME e beta-amiloide, a glia foi ativada. Esses achados demonstram um papel do resveratrol na ação neuroprotetora e de neurorresgate.

Palavras-chave: 2-metoxietanol, resveratrol, neurotóxico, neuroprotetor, neurorresgate.

\section{Introduction}

Phthalates is one of the compounds used in the manufacture of fragrances, cosmetics, lotions and plastics processing. These compounds are embedded in the plastic structure as "plasticizers" and can be breakdown from the plastic structure, if they are exposed to heat (Johanson, 2000). More than 18 million pounds of phthalates have been used annually and poisoning of these compounds can occur every day, through breathing air and exposure through the skin (Adibi et al., 2008). Phthalic esters in the body are metabolized become methoxyacetic acid (MAA) and 2-methoxyethanol (2-ME). 2-ME is an industrial solvent produced by the reaction of ethylene oxide with anhydrous methanol (Kirk and Othmer, 1980; WHO, 2009). This compound is a colorless, volatile liquid, with high water solubility and used in chemical intermediate, solvent coupler of mixtures and water-based formulations. Although, in recent years 2-ME was declined in some countries by other substances due to risk management procedures, it is still in use in some areas. Several studies have shown that 2-ME is to induce neoplastic effects caused corticogenesis disorder. The disorder caused by the existence of these proteins as a result of 2-Methoxyethanol (WHO, 2009).

Resveratrol (3,5,4'-trihydroxy-trans-stilbene) is found in grape skins, berries, and red wine as well as peanuts and other nuts (Baur and Sinclair, 2006). These compounds is increase antioxidant defenses and decrease proinflammatory cytokines in hippocampal astrocyte cultures (Bellaver et al., 2015), as alternative treatment options in Alzheimer's disease (AD), can decrease the toxicity, aggregation of $A \beta$ peptides in hippocampus of $\mathrm{AD}$ patients, promote neurogenesis, and prevent hippocampal damage (Gomes et al., 2018). The role of resveratrol as a neuroprotective agent can be mediated by astrocytes (Daverey and Agrawal, 2018), and the cAMP response element binding (CREB) protein. CREB is a protein in the neurotrophin family that is involved in neuroprotection, including neuronal survival, synaptic plasticity, and neurodevelopment, and is also involved in the pathophysiology of nerve degeneration (Kapczinski et al., 2008). Other studies also showed that resveratrol can inhibit beta-amyloid in microglia and astrocytes also has anti-inflammatory functions (Lu et al., 2010).

It is clear that the health and proper functioning of astrocytes are important for protecting neurons from various cellular insults (Okada et al., 2018). Oxidative stress as direct response has effect on the damage to astrocyte and neuron function that occurs during several neurodegenerative diseases (Molofsky et al., 2012; Phatnani and Maniatis, 2015). Thus, alleviating oxidative stress is a potential therapeutic approach to halt and reduce the inflammation and apoptosis in astrocytes.
Resveratrol may act as an antioxidant by modulating intracellular signaling pathways. One important intracellular signaling system is protein kinase C (PKC), a family of 12 serine/threonine kinases.

PKC has been found to modulate cell viability, resulting in the protection of various neuronal cells (Behrens et al., 1999; Cordey et al., 2003; Doré et al., 1999; Maher, 2001; Xie et al., 2000). This pathway is assumed to be involved in the neuroprotective effects of resveratrol against A $\beta$ (Beta Amyloid)-induced neurotoxicity (Han et al., 2004). Resveratrol treatment against $A \beta$-related oxidative stress was examined in a cell culture model (human-derived SH-SY5Y neuroblastoma cell cultures), was shown to maintain cell viability and exert an anti-oxidative effect by enhancing the intracellular free radical scavenger glutathione (Lange and Li, 2018). Moreover, resveratrol treatment was cultured hippocampal to improve learning and memory (Zhao et al., 2013). Perhaps that is the reason that the addition of resveratrol effectively increased cell survival and decreased cell apoptosis (Sun et al., 2010). This observation, together with the fact that 2-ME and its metabolites can damage in cerebral cortex of mice (Irnidayanti et al., 2013), led us to investigate the potential of neurotoxicity of 2-ME and neuroprotective of resveratrol isolated from tempeh and soybean seed coats in primary cortical neuron cultures.

\section{Materials and Methods}

\subsection{Preparation of resveratrol and 2-methoxyethanol (2-ME)}

The trans-resveratrol standard (cat no. R5010) was obtained from Sigma Aldrich. Trans-resveratrol was also isolated from tempeh and soybean seed coats (Irnidayanti and Sutiono, 2019a, b). This compound was dissolved in distilled water at concentrations of $1.4 \mu \mathrm{g} / \mathrm{mL}, 2.8 \mu \mathrm{g} / \mathrm{mL}$ and $4.2 \mu \mathrm{g} / \mathrm{mL}$. 2-ME (cat no. 284467) was obtained from Sigma Chemical Aldrich and dissolved in distilled water at a concentration of $7.5 \mathrm{mmol} / \mathrm{L}$. In this study, the highest concentration of 2-ME in culture medium was less than $0.1 \%$ and it did not affect cell viability.

\subsection{Culture media}

Neurobasal Medium (cat no.12349-015,Gibco), 1\% GlutaMAX (cat no. 35050-061, Gibco), 1\% penicillinstreptomycin (P4333-20 mL, Sigma), and 2\% B-27 supplemented (cat no. 175054-044 Gibco) with $10 \mathrm{~mL}$ of $10 \%$ fetal bovine serum (cat no. S181H-500, Biowest) was used as complete media. Nine hundred microliters of trypsin-EDTA (cat no. L0930-100), $10 \mathrm{mg}$ DNase $100 \mu \mathrm{g} / \mathrm{mL}$ (cat no.A3778,0010, Applichem) in $3 \mathrm{~mL}$ of cold Dulbecco's phosphate-buffered saline (cat no. P0750-N1L, Biowest). FBS 10\% in DMEM (cat. no. L0104-500, Biowest). 


\subsection{Preparation of the cell suspension for the cell culture assay}

The cerebral cortex was dissected from fetal mice (Mus musculus, Swiss Webster) brains on the 19th gestations day. The cerebral cortex was placed in $3 \mathrm{~mL}$ of cold PBS solution containing $900 \mu \mathrm{L}$ of trypsin-EDTA solution and $100 \mu \mathrm{g} / \mathrm{mL}$ DNase and 10\% FBS-DMEM was added, followed by incubation for 15 minutes with an AUTOFLOW IR Water-Jacketed CO2 Incubator (NUARE) and centrifugation (Hitachi Centrifuge Type CT6EL cat no. 905601$)$ at $300 \times \mathrm{g}$ for 3 minutes. The cells were grown at $37{ }^{\circ} \mathrm{C}, 5 \% \mathrm{CO}_{2}$ and $90 \%$ relative humidity until the sub confluent stage. The cells were then harvested by treatment with trypsin-EDTA solution. The number of cells was counted in a hemocytometer, and the cell density was adjusted to 10,000 cells/mL in complete media. Neurons were plated on poly-D-lysine-coated dishes in neurobasal containing 1\% GlutaMAX, 1\% penicillin-streptomycin, 2\% B-27 supplement, and 10\% fetal bovine serum, maintained in this manner for confluent stages at $37{ }^{\circ} \mathrm{C}, 5 \% \mathrm{CO}_{2}$ and $90 \%$ relative humidity. The use and care of animals were in accordance with the statements of the Guide for Animal Experimentation of the Medical School of the University of Indonesia.

\subsection{The MTT assay was carried out in triplicate in 96-well microtiter culture plates}

The MTT assay was carried out for determining mitochondrial dehydrogenase activity in living cells. (3-(4,5-Dimethylthiazol-2-yl)-2,5-diphenyl tetrazolium bromide (MTT), a tetrazole, is reduced to purple formazan by NADH in the mitochondria of living cells. The absorbance of this colored solution can be quantified by measuring at a certain wavelength (usually between 540 and $570 \mathrm{~nm}$ ) by an ELISA. The IC50 and $\mathrm{R}^{2}$ values were calculated using graphs generated from Microsoft Excel, 2007 edition.

A total of $100 \mu \mathrm{L}$ of the cell suspension ( 7500 cells) was added to each well of the 96-well plates and incubated at $37{ }^{\circ} \mathrm{C}, 5 \% \mathrm{CO}_{2}$ and $90 \%$ relative humidity for 7 days. The cells were washed with PBS and the medium changed to neurobasal medium without supplemented material for $2 \mathrm{~h}$. Cells were treated with three different concentrations (1.4, 2.8 and $4.2 \mu \mathrm{g} / \mathrm{mL}$ ) resveratrol extract (standard, tempeh and soybean seed coats). The plates were incubated for an additional period of 60 minutes in the $\mathrm{CO}_{2}$ incubator. In control wells, only medium was added. Ten microliters of $5 \mathrm{mg} / \mathrm{mL}$ MTT was added to each well, and the plates were incubated for $3 \mathrm{~h}$. At the end of the incubation period, the culture media was carefully removed, and $100 \mu \mathrm{L}$ of MTT solvent was added to each well. After covering the plates with aluminum foil, the plates were incubated at room temperature for $18 \mathrm{~h}$. The absorbance was measured at $540 \mathrm{~nm}$ with a reference filter of $570 \mathrm{~nm}$ with Microplate Elisa Reader.

\subsection{Cytotoxicity of beta-amyloid incubated with resveratrol}

Cell viability was examined by the Biotium assay. In brief, $100 \mu \mathrm{L}$ of the cell suspension (7,500 cells) was added into each well of the $3 \mathrm{~mL}$ sterile culture plates and incubated at $37^{\circ} \mathrm{C}, 5 \% \mathrm{CO}_{2}$ and $90 \%$ relative humidity for 7 days. Cell fractions were washed with PBS and the medium was changed to neurobasal medium without supplemented material for $2 \mathrm{~h}$. Cells were treated with three different concentrations $(1.4,2.8$ and $4.2 \mu \mathrm{g} / \mathrm{mL}$ ) resveratrol (standard, tempeh and soybean seed coats), and the plates were incubated for an additional period of 60 minutes in the $\mathrm{CO}_{2}$ incubator. Cells were washed again with PBS, the medium was exchanged for $500 \mu \mathrm{L}$ of Biotium solution ( $2 \mathrm{~mL}$ of casein, $10 \mu \mathrm{L}$ of EtBr and $5 \mathrm{~mL}$ of PBS) per sterile petri dish and incubated for 30 minutes. Biotium assay was employed here as an indicator of the primary cortical neuron cells proliferation and neural cytotoxicity, which is extensively used as a qualitative and reliable Fluorescent Imaging for cell viability. Exposure of the primary cortical neuron cells to $5 \mu \mathrm{g} / \mathrm{mL}$ of BetaAmyloid monoclonal Antibody (LN27) Thermo Fisher pre-incubated for $24 \mathrm{~h}$ with $10 \mu \mathrm{L}$ of $4.2 \mu \mathrm{g} / \mathrm{mL}$ Resveratrol and $7.5 \mathrm{mmol} / \mathrm{L}$ 2-Methoxyethanol additions in sterile 12-well plate. Cells were observed with a fluorescence microscope (ZOE, Bio-Rad).

\section{Results and Discussion}

\subsection{Results}

Administration of a 2-ME dose of $10 \mathrm{mM}$ and resveratrol at doses of $1.4,2.8$ or $4.2 \mu \mathrm{g} / \mathrm{mL}$ indicated that the resveratrol could increase the viability of neuronal cells. Following the increase of concentrations of resveratrol (standard, tempeh and soybean seed coat), the percent live cells increased gradually up to $100 \%$ (Tables 1 and 2 ). In the control group, the cells grew well and formed neuronal networks after 7 days of in vitro culture (Figure 1). When exposed to $4.2 \mu \mathrm{g} / \mathrm{mL}$ all resveratrol, the majority of the cells grew well (Figures 2, 3 and 4). In contrast, after exposure to 2-methoxyethanol, the neurons began to die (Figure 5). The susceptibility of cells to 2-ME+resveratrol exposure was characterized by IC50 values. IC50 values refer to the classification of Gessler et al. (1994); the inhibitory activity of test substances in vitro is divided into three categories: (a) the best activity is when the IC50 value is less than $10 \mu \mathrm{g} / \mathrm{mL}$, the activity is good if the IC50 value is between $10-50 \mu \mathrm{g} / \mathrm{mL}$, and the activity is not good if the IC50 value is more than $50 \mu \mathrm{g} / \mathrm{mL}$. This interpretation of the IC50 value illustrates the ability of a resveratrol concentration to inhibit nerve cell growth in vitro by $50 \%$. The lower the IC50 value, the higher the effectiveness of resveratrol inhibition on the growth of nerve cells. Table 3 shows that the cytotoxic activities of resveratrol from the soybean seed coats (IC50: $17.43 \mu \mathrm{g} / \mathrm{mL}$ ) and standard resveratrol (IC50:17.64 $\mu \mathrm{g} / \mathrm{mL}$ ) were lower than that of resveratrol from tempeh (IC50: $32.22 \mu \mathrm{g} / \mathrm{mL}$ ). Table 4 indicated that cytotoxic activities of resveratrol from the soybean seed coats (IC50: $13.40 \mu \mathrm{g} / \mathrm{mL}$ ) and standard resveratrol (IC50:17.38 $\mu \mathrm{g} / \mathrm{mL}$ ) were also lower than that of resveratrol from tempeh (IC50: $31.14 \mu \mathrm{g} / \mathrm{mL}$ ). Nevertheless, all of the resveratrol samples tested had IC50 values between $10-50 \mu \mathrm{g} / \mathrm{mL}$ (good activity), and can therefore serve as a good source of bioactivity.

Result of viability cell assay was found from the resveratrol isolated from tempeh, soybean seed coat and 
Table 1. Effect of Various concentrations of Resveratrol and 2-Methoxyethanol against Primary Neuron cell viability (540 $\mathrm{nm}$ ).

\begin{tabular}{|c|c|c|c|}
\hline \multirow{3}{*}{$\begin{array}{c}\text { Concentration of 2-Methoxyethanol } \\
\text { and Resveratrol }\end{array}$} & \multicolumn{3}{|c|}{ \% Cell Viability } \\
\hline & 2-ME (10mM) & 2-ME (10mM) & 2-ME (10mM) \\
\hline & Resveratrol (Standard) & Resveratrol (Tempeh) & $\begin{array}{l}\text { Resveratrol (Soybean } \\
\text { Seed Coat) }\end{array}$ \\
\hline $1.4(\mu \mathrm{g} / \mathrm{mL})$ & 88.2 & 100 & 92.05 \\
\hline $2.8(\mu \mathrm{g} / \mathrm{mL})$ & 94.73 & 100 & 85.59 \\
\hline $4.2(\mu \mathrm{g} / \mathrm{mL})$ & 100 & 100 & 100 \\
\hline
\end{tabular}

Table 2. Effect of Various concentrations of Resveratrol and 2-Methoxyethanol against Primary Neuron cell viability (570 nm).

\begin{tabular}{|c|c|c|c|}
\hline \multirow{3}{*}{$\begin{array}{l}\text { Concentration of 2-Methoxyethanol } \\
\text { and Resveratrol }\end{array}$} & \multicolumn{3}{|c|}{ \% Cell Viability } \\
\hline & 2-ME (10mM) & 2-ME (10mM) & 2-ME (10mM) \\
\hline & Resveratrol (Standard) & Resveratrol (Tempeh) & $\begin{array}{l}\text { Resveratrol (Soybean } \\
\text { Seed Coat) }\end{array}$ \\
\hline $1.4(\mu \mathrm{g} / \mathrm{mL})$ & 87.43 & 100 & 88.02 \\
\hline $2.8(\mu \mathrm{g} / \mathrm{mL})$ & 95.41 & 98.25 & 82.97 \\
\hline $4.2(\mu \mathrm{g} / \mathrm{mL})$ & 100 & 100 & 100 \\
\hline
\end{tabular}

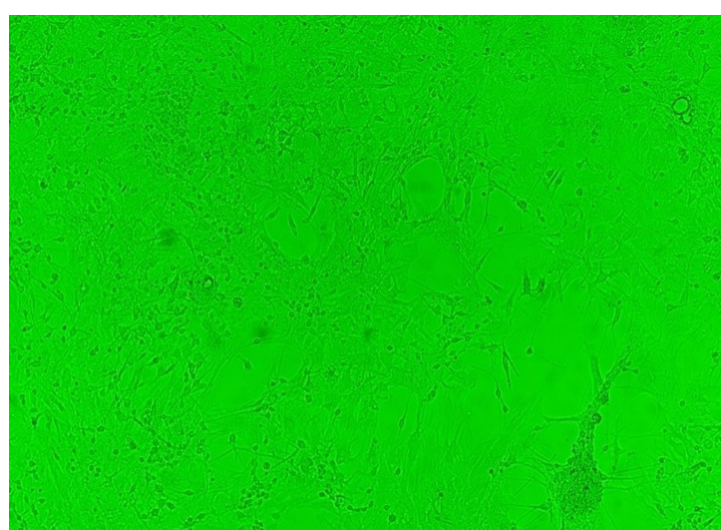

Figure 1. Control Group (10 x10).

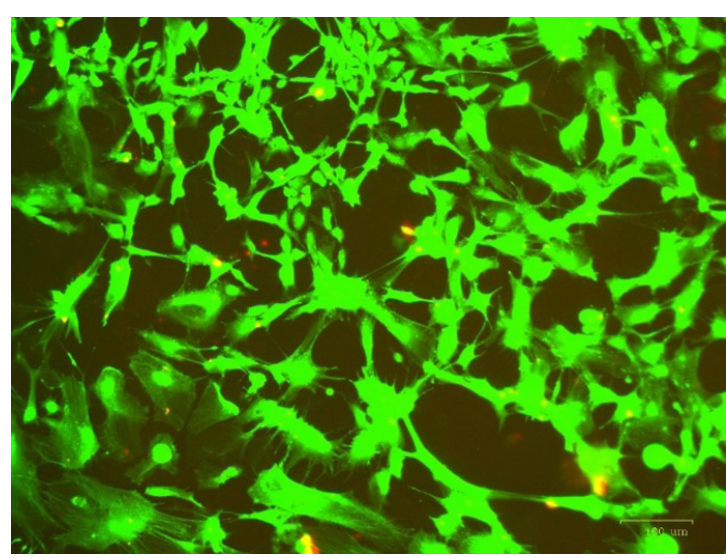

Figure 2. Treatment group : $2-\mathrm{ME}+$ Resveratrol Standard (10 x10).

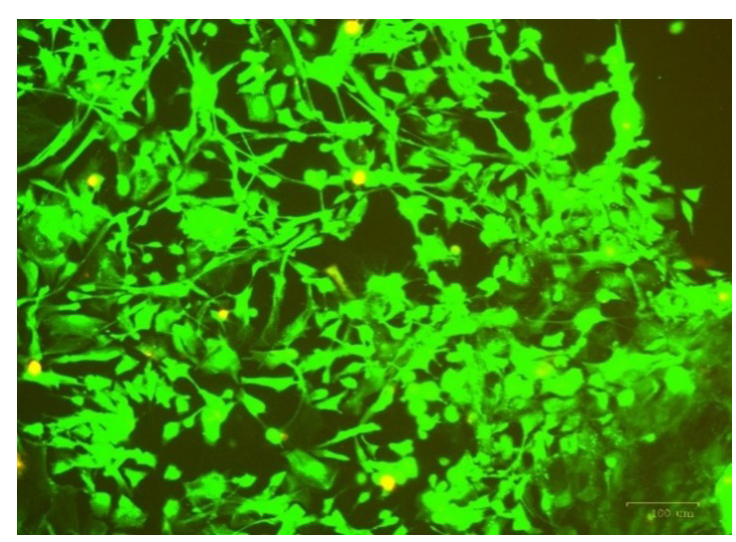

Figure 3. Treatment group : 2- ME + Resveratrol isolated from Tempeh (10 x10).

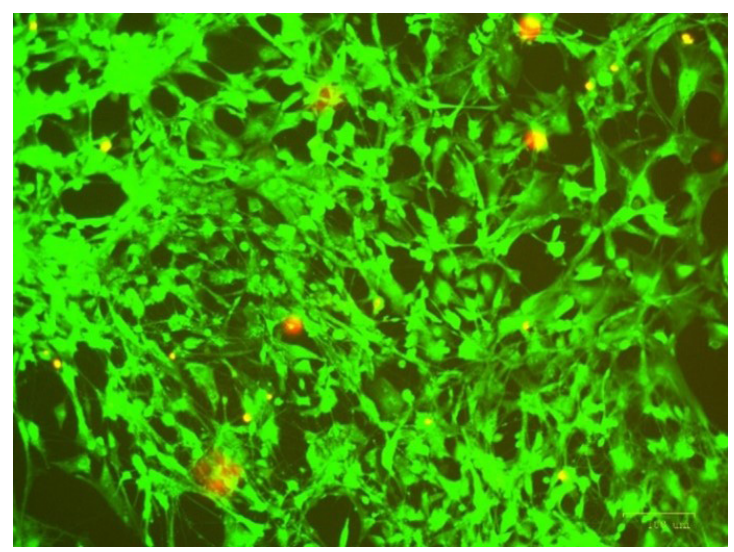

Figure 4. Treatment group : 2- ME + Resveratrol isolated from Soybean seed coat $(10 \times 10)$. 
standard, which shows all viability value are $100 \%$ and can be used as an anti-apoptotic agent. These data are supported by images of the neuronal culture cells. In the control group, the cells grew well and formed neuronal networks after 7 days of in vitro culture (Figure 1). Surviving cells are shown with green fluorescence, and apoptotic cells are shown with red fluorescence (Figure 2, 3, 4 and 5). More bright red cells were visible in the 2-ME group (Figure 5), while few apoptotic cells were detected in the 2-ME + resveratrol group (Figure 2, 3 and 4). When $1.4 \mu \mathrm{g} / \mathrm{mL}$, $2.8 \mu \mathrm{g} / \mathrm{mL}$ or $4.2 \mu \mathrm{g} / \mathrm{mL}$ resveratrol was added to the culture medium, the number of cells with bright red nuclei

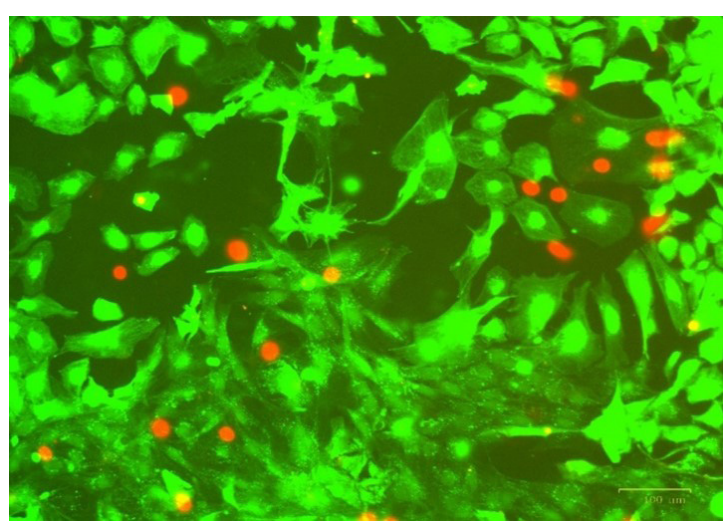

Figure 5. Treatment group : 2- ME (10 x10). decreased, showing that resveratrol attenuated neuronal apoptosis. This result indicates that the neuroprotective effect strengthens with an increase in the concentration of resveratrol.

Although we cannot exclude the possibility that resveratrol $4.2 \mu \mathrm{g} / \mathrm{mL}$ isolated from Tempe had some direct effects on neurons, since evidence suggest that such effects played only a minor. The administration of resveratrol $4.2 \mu \mathrm{g} / \mathrm{mL}$ isolated from Tempe compared with resveratrol standard (Figure 6), indicating that resveratrol strongly attenuates Beta-amyloid by decreasing in the number of death cells examined by biotium assay (Figures $7 \& 8$ ). In the presence of $4.2 \mu \mathrm{g} / \mathrm{mL}$ resveratrol, the levels of death cells of 2-Methoxyehanol induced were relatively marked lower. In cultures exposure with 2-Methoxyethanol alone, Beta-amyloid induced a significant increase in the number of death cells examined by Biotium assay, most of which were glia (Figure 9).

\section{Discussion}

In this study, we addressed whether 2-methoxyethanolinduced neurotoxicity can be inhibited by resveratrol. Our results showed that resveratrol isolated from tempeh and soybean seed coats increased neuronal viability and decreased cell apoptosis. Therefore, the neuroprotection of resveratrol against 2-methoxyethanol neurotoxicity is possibly mediated by induced NO (nitric oxide) production,

Table 3. Cytotoxic effect of various concentrations of Resveratrol and 2-Methoxyethanol Against Primary Neuron cell viability in MTT assay $(540 \mathrm{~nm})$.

\begin{tabular}{|c|c|c|c|}
\hline \multirow{3}{*}{$\begin{array}{c}\text { Concentration of 2-Methoxyethanol } \\
\text { and Resveratrol }\end{array}$} & \multicolumn{3}{|c|}{ \% Inhibition } \\
\hline & 2-ME (10mM) & 2-ME (10mM) & 2-ME (10mM) \\
\hline & Resveratrol (Standard) & Resveratrol (Tempeh) & $\begin{array}{l}\text { Resveratrol (Soybean } \\
\text { Seed Coat) }\end{array}$ \\
\hline IC50 & $(17.64 \pm 0.99 \mu \mathrm{g} / \mathrm{mL})$ & $(32.22 \pm 1.18 \mu \mathrm{g} / \mathrm{mL})$ & $(17.43 \pm 0.16 \mu \mathrm{g} / \mathrm{mL})$ \\
\hline $1.4(\mu \mathrm{g} / \mathrm{mL})$ & 11.8 & 0 & 7.95 \\
\hline $2.8(\mu \mathrm{g} / \mathrm{mL})$ & 5.27 & 0 & 14.41 \\
\hline $4.2(\mu \mathrm{g} / \mathrm{mL})$ & 0 & 0 & 0 \\
\hline
\end{tabular}

Table 4. Cytotoxic effect of various concentrations of Resveratrol and 2-Methoxyethanol Against Primary Neuron cell viability in MTT assay $(570 \mathrm{~nm})$.

\begin{tabular}{|c|c|c|c|}
\hline \multirow{3}{*}{$\begin{array}{c}\text { Concentration of 2-Methoxyethanol } \\
\text { and Resveratrol }\end{array}$} & \multicolumn{3}{|c|}{ \% Inhibition } \\
\hline & 2-ME (10mM) & 2-ME (10mM) & 2-ME (10mM) \\
\hline & Resveratrol (Standard) & Resveratrol (Tempeh) & $\begin{array}{l}\text { Resveratrol (Soybean } \\
\text { Seed Coat) }\end{array}$ \\
\hline IC50 & $(17.38 \pm 0.99 \mu \mathrm{g} / \mathrm{mL})$ & $(31.14 \pm 0.02 \mu \mathrm{g} / \mathrm{mL})$ & $(13.40 \pm 0.30 \mu \mathrm{g} / \mathrm{mL})$ \\
\hline $1.4(\mu \mathrm{g} / \mathrm{mL})$ & 12.57 & 0 & 11.98 \\
\hline $2.8(\mu \mathrm{g} / \mathrm{mL})$ & 4.59 & 1.75 & 17.03 \\
\hline $4.2(\mu \mathrm{g} / \mathrm{mL})$ & 0 & 0 & 0 \\
\hline
\end{tabular}




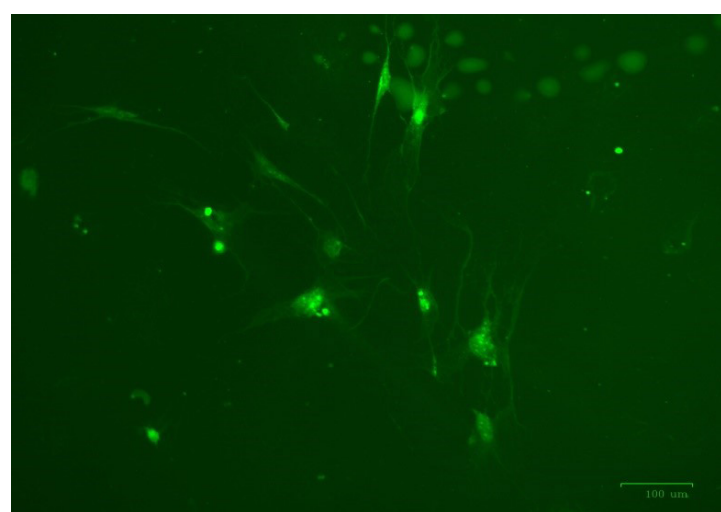

Figure 6. Treatment Group with resveratrol standard after induced by Beta-Amyloid ( $10 \times 10)$.

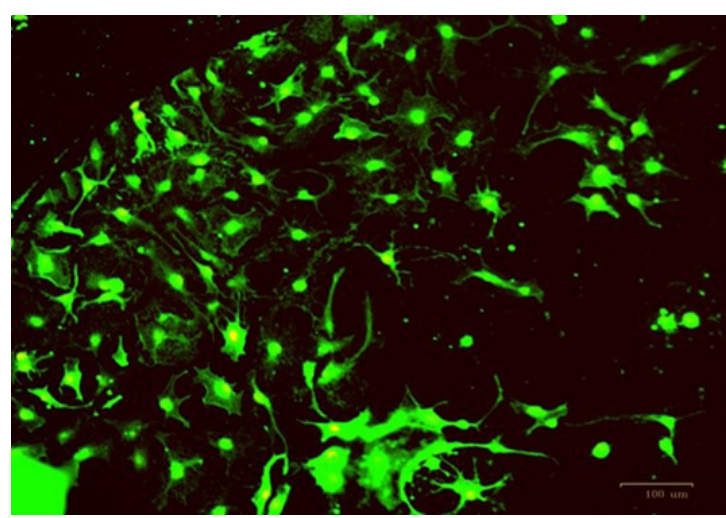

Figure 7. Treatment Group with resveratrol tempeh after induced by Beta-Amyloid ( $10 \times 10)$.

and resveratrol significantly protected cells from free radical overload induced neuronal death (Lu et al., 2006). The results of the MTT study of all resveratrol samples at a dose of $4.2 \mu \mathrm{g} / \mathrm{mL}$ showed $0 \%$ inhibition against neuronal cell culture in $100 \%$ viable cells, but resveratrol from soybean seed coats showed good activity (IC50: 10-50 $\mu \mathrm{g} / \mathrm{mL}$ ). The cytotoxicity of resveratrol may be due to the presence of flavonoids, which have been reported to have cytotoxic activity due to the presence of phenolic groups (Matsuo et al., 2005).

In our culture model, Resveratrol $4.2 \mu \mathrm{g} / \mathrm{mL}$ isolated from Tempe clearly prevented microglia-dependent Beta-Amyloid toxicity against 2-ME (Figure 6, 7 and 9). Resveratrol isolated from tempeh may facilitate the antiapoptotic mechanism and/or inhibit the proapoptotic mechanism by regulating certain specific signaling pathways than resveratrol standard. In particular, the underlying mechanism and found that resveratrol shows better anti-apoptotic output and supports the fact that resveratrol is less toxic to astrocytes for longer periods of time (Daverey and Agrawal, 2018). It has been shown that resveratrol samples isolated from tempeh have a positive effect on glia's cells. Based on previous research (Almeida et al., 2009; Yeung et al., 2004) shown than resveratrol can overexpression SIRT1 and activated microglia induced by beta amyloid. The effects of resveratrol on increasing viability and preventing apoptosis are

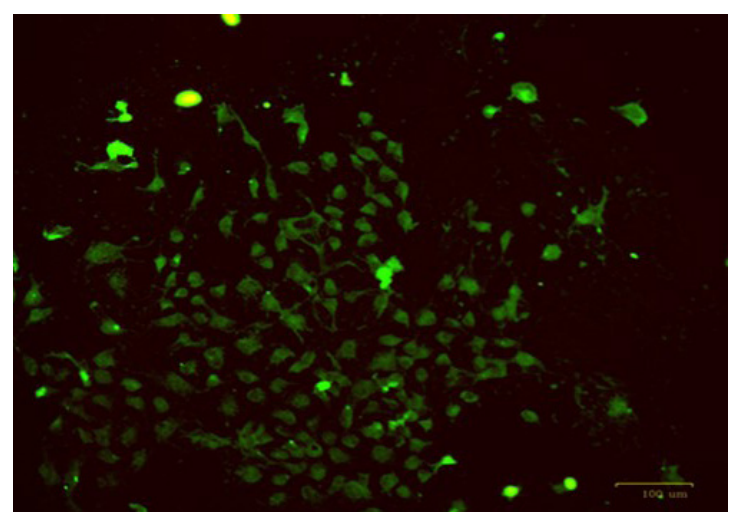

Figure 8. Treatment Group with resveratrol tempeh + 2-ME after induced by Beta-Amyloid (10 x10).

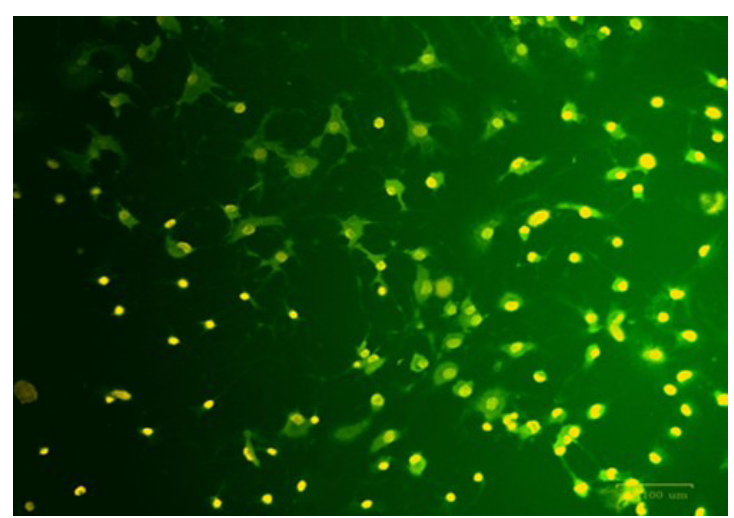

Figure 9. Treatment Group with 2-ME after induced by BetaAmyloid (10 x10).

mediated by the Shh signaling pathway. Shh signaling may act on Sirt1 to exert these effects (Tang et al., 2017). It is obvious that glial are important for protecting neurons from various cellular offended and oxidative stress as direct response that occurs during 2-ME induced to cells culture of cerebral cortex. Therefore, resveratrol may be having neuroprotective effect to glia cells and we recommend that further research be conducted to substantiate the neuroprotective effects of resveratrol isolated from tempeh on glial cell cultures. Interestingly, resveratrol was mostly focused on the neuroprotective-neurorescuing properties against the neurotoxic effects (Jang and Surh, 2003). The neuroprotective-neurorescuing action of resveratrol is especially against beta amiloid-induced neurotoxicity (Hardy and Selkoe, 2002).

\section{Conclusion}

This finding shows the role of resveratrol in nerve protection. Resveratrol at a dose of $2.4 \mu \mathrm{g} / \mathrm{mL}$ can increase cell viability to $100 \%$ and inhibit cell death from reaching $0 \%$ in primary neuronal cell cultures. This research demonstrated that resveratrol, a natural product isolated from tempeh and soybean seed coats, protected neurons against 2-methoxyethanol-induced damage to cells of cerebral cortex 


\section{Acknowledgements}

This project is supported by Ministry of Research, Technology and Higher Education of the Republic of Indonesia (Grant contract no: 4/SP2H/ DRPM/ LPPM-UNJ/ III/2019). We would like to thanks for Research Center for Biotechnology and BSL3, (LIPI) Indonesia.

\section{References}

ADIBI, J.J., WHYATT, R.M., WILLIAMS, P.L., CALAFAT, A.M., CAMANN, D., HERRICK, R., NELSON, H., BHAT, H.K., PERERA, F.P., SILVA, M.J. and HAUSER, R., 2008. Characterization of phthalate exposure among pregnant women assessed by repeat air and urine samples. Environmental Health Perspectives, vol. 116, no. 4, pp. 467-473. http://dx.doi.org/10.1289/ehp.10749. PMid:18414628.

ALMEIDA, L., VAZ-DA-SILVA, M., FALCÃO, A., SOARES, E., COSTA, R., LOUREIRO, A.I., FERNANDES-LOPES, C., ROCHA, J.F., NUNES, T., WRIGHT, L. and SOARES-DA-SILVA, P., 2009. Pharmacokinetic and safety profile of trans-resveratrol in a rising multiple dose study in healthy volunteers. Molecular Nutrition \& Food Research, vol.53, suppl. 1, pp. s7-s15. http://dx.doi.org/10.1002/ mnfr.200800177. PMid:19194969.

BAUR, J.A. and SINCLAIR, D.A., 2006. Therapeutic potential of resveratrol : the in vivo evidence. Nature Reviews. Drug Discovery, vol. 5, no. 6, pp. 493-506. http://dx.doi.org/10.1038/nrd2060. PMid: 16732220.

BEHRENS, M.M., STRASSER, U., KOH, J.Y., GWAG, B.J. and CHOI, D.W., 1999. Prevention of neuronal apoptosis by phorbol ester-induced activation of protein kinase $\mathrm{C}$ : blockade of p38 mitogen-activated protein kinase. Neuroscience, vol. 94, no. 3, pp. 917-927. http:// dx.doi.org/10.1016/S0306-4522(99)00212-2. PMid:10579584.

BELLAVER, B., SOUZA, D.G., BOBERMIN, L.D., SOUZA, D.O., GONCALVES, C.A. and QUINCOZES-SANTOS, A., 2015. Resveratrol protects hippocampal astrocytes against LPSinduced neurotoxicity through HO-1, p38 and ERK pathways. Neurochemical Research, vol. 40, no. 8, pp. 1600-1608. http:// dx.doi.org/10.1007/s11064-015-1636-8. PMid:26088684.

CORDEY, M., GUNDIMEDA, U., GOPALAKRISHNA, R. and PIKE, C.J., 2003. Estrogen activates protein kinase $C$ in neurons: role in neuroprotection. Journal of Neurochemistry, vol. 84, no. 6, pp. 1340-1348. http://dx.doi.org/10.1046/j.1471-4159.2003.01631.x. PMid:12614334.

DAVEREY, A. and AGRAWAL, S.K., 2018. Pre and post treatment with curcumin and resveratrol protects astrocytes after oxidative stress. Brain Research, vol. 1692, pp. 45-55. http://dx.doi. org/10.1016/j.brainres.2018.05.001. PMid:29729252.

DORÉ, S., TAKAHASHI, M., FERRIS, C.D., ZAKHARY, R., HESTER, L.D., GUASTELLA, D. and SNYDER, S.H., 1999. Bilirubin, formed by activation of heme oxygenase-2, protects neurons against oxidative stress injury. Proceedings of the National Academy of Sciences of the United States of America, vol. 96, no. 5, pp. 24452450. http://dx.doi.org/10.1073/pnas.96.5.2445. PMid:10051662.

GESSLER, M.C., NKUNYA, M.H., MWASUMBI, L.B., HEINRICH, M. and TANNER, M., 1994. Screening tanzanian medical plants for antimalarial activity. Acta Tropica, vol. 56, no. 1, pp. 65-77. http:// dx.doi.org/10.1016/0001-706X(94)90041-8. PMid:8203297.

GOMES, B.A.Q., SILVA, J.P.B., ROMEIRO, C.F.R., SANTOS, S.M., RODRIGUES, C.A., GONÇALVES, P.R., SAKAI, J.T., MENDES, P.F.S., VARELA, E.L.P. and MONTEIRO, M.C., 2018. Neuroprotective mechanisms of resveratrol in Alzheimer's disease: role of SIRT1. Oxidative Medicine and Cellular Longevity, vol. 2018, 8152373. http://dx.doi.org/10.1155/2018/8152373. PMid:30510627.
HAN, Y.S., ZHENG, W.H., BASTIANETTO, S., CHABOT, J.G. and QUIRION, R., 2004. Neuroprotective effects of resveratrol against $\beta$-amyloid-induced neurotoxicity in rat hippocampal neurons: involvement of protein kinase C. British Journal of Pharmacology, vol. 141, no. 6, pp. 997-1005. http://dx.doi. org/10.1038/sj.bjp.0705688. PMid:15028639.

HARDY, J. and SELKOE, D.J., 2002. The amyloid hypothesis of Alzheimer's disease: progress and problems on the road to therapeutics. Science, vol. 297, no. 5580, pp. 353-356. http:// dx.doi.org/10.1126/science.1072994. PMid:12130773.

IRNIDAYANTI, Y. and SUTIONO, D.R., 2019a. Tempeh \& Soybean seed coat: the alternative sources of trans-resveratrol as neuroprotective agents. International Journal of Morphology, vol. 37, no. 3, pp. 1164-1171. http://dx.doi.org/10.4067/S0717-95022019000301164.

IRNIDAYANTI, Y. and SUTIONO, D.R., 2019b. Unlighted maceration and ultrasound technique: the key to gaining stable transresveratrol from alternative sources in tempeh and soybean seed coat. Pakistan Journal of Nutrition, vol. 18, no. 6, pp. 548553. http://dx.doi.org/10.3923/pjn.2019.548.553.

IRNIDAYANTI, Y., DARMANTO, W., ABADI, A., HATTORI, Y. and YAMASHIRO, Y., 2013. Differential expression of Vimentin and GFAP protein during brain development of mouse fetuses after treated with 2-methoxyethanol. ITB Journal of Science, vol. 44, no. 4, pp. 346-357. http://dx.doi.org/10.5614/itbj.sci.2012.44.4.5.

JANG, J.H. and SURH, Y.J., 2003. Protective effects of resveratrol on b-amyloid-induced oxidative PC12 cell death. Free Radical Biology \& Medicine, vol. 34, no. 8, pp. 1100-1110. http://dx.doi. org/10.1016/S0891-5849(03)00062-5. PMid:12684095.

JOHANSON, G., 2000. Toxicity review of ethylene glycol monomethyl ether and its acetate ester. Critical Reviews in Toxicology, vol. 30, no. 3, pp. 307-345. http://dx.doi. org/10.1080/10408440091159220. PMid:10852499.

KAPCZINSKI, F., FREY, B.N., KAUER-SANT'ANNA, M. and GRASSIOLIVEIRA, R., 2008. Brain-derived neurotrophic factor and neuroplasticity in bipolar disorder. Expert Review of Neurotherapeutics, vol. 8, no. 7, pp. 1101-1113. http://dx.doi. org/10.1586/14737175.8.7.1101. PMid:18590480.

KIRK, R.E. and OTHMER, D.F., 1980. Encyclopedia of chemical technology. 3rd ed. New York: John Wiley \& Sons.

LANGE, W. and LI, S., 2018. Resveratrol, pterostilbene, and dementia. BioFactors, vol. 44, no. 1, pp. 83-90. http://dx.doi.org/10.1002/ biof.1396. PMid:29168580.

LU, K.T., CHIOU, R.Y., CHEN, L.G., CHEN, M.H., TSENG, W.T., HSIEH, H.T. and YANG, Y.L., 2006. Neuroprotective effects of resveratrol on cerebral ischemia-induced neuron loss mediated by free radical scavenging and cerebral blood flow elevation. Journal of Agricultural and Food Chemistry, vol. 54, no. 8, pp. 31263131. http://dx.doi.org/10.1021/jf053011q. PMid:16608241.

LU, X., MA, L., RUAN, L., KONG, Y., MOU, H., ZHANG, Z., WANG, Z., WANG, J.M. and LE, Y., 2010. Resveratrol differentially modulates inflammatory responses of microglia and astrocytes. Journal of Neuroinflammation, vol. 7, no. 1, pp. 46. http://dx.doi. org/10.1186/1742-2094-7-46. PMid:20712904.

MAHER, P., 2001. How protein kinase C activation protects nerve cells from oxidative stress-induced cell death. Journal of Neuroscience Research, vol. 21, no. 9, pp. 2929-2938. PMid:11312276.

MATSUO, M., SASAKI, N., SAGA, K. and KANEKO, T., 2005. Cytotoxicity of flavonoids toward cultured normal human cells. Biological \& Pharmaceutical Bulletin, vol. 28, no. 2, pp. 253259. http://dx.doi.org/10.1248/bpb.28.253. PMid:15684479.

MOLOFSKY, A.V., KRENICK, R., ULLIAN, E., TSAI, H., DENEEN, B., RICHARDSON, W.D., BARRES, B.A. and ROWITCH, D.H., 2012. Astrocytes and disease: a neurodevelopmental perspective. 
GENE E DEV., vol. 26, no. 9, pp. 891-907. http://dx.doi.org/10.1101/ gad.188326.112. PMid:22549954.

OKADA, S., HARA, M., KOBAYAKAWA, K., MATSUMOTO, Y. and NAKASHIMA, Y., 2018. Astrocyte reactivity and astrogliosis after spinal cord injury.Journal of Neuroscience Research, vol. 126, pp. 3943. http://dx.doi.org/10.1016/j.neures.2017.10.004. PMid:29054466.

PHATNANI, H. and MANIATIS, T., 2015. Astrocytes in neurodegenerative disease. Cold Spring Harbor Perspectives in Biology, vol. 7, no. 6, pp. a020628. http://dx.doi.org/10.1101/ cshperspect.a020628. PMid:25877220.

SUN, A.Y., WANG, Q., SIMONYI, A. and SUN, G.Y., 2010. Resveratrol as a therapeutic agent for neurodegenerative diseases. Molecular Neurobiology, vol. 41, no. 2-3, pp. 375-383. http://dx.doi. org/10.1007/s12035-010-8111-y. PMid:20306310.

TANG, F., GUO, S., LIAO, H., YU, P., WANG, L., SONG, X., CHEN, J. and YANG, Q., 2017. Resveratrol enhances neurite outgrowth and synaptogenesis via sonic hedgehog signaling following oxygen-glucose deprivation/reoxygenation injury. Cellular Physiology and Biochemistry, vol. 43, no. 2, pp. 852-869. http:// dx.doi.org/10.1159/000481611. PMid:28957797.
WORLD HEALTH ORGANIZATION - WHO, 2009. Selected alkoxyethanols: 2-methoxyethanol. Surrey, United Kingdom: Toxicology Advice \& Consulting Ltd. Concise International Chemical Assessment Document, no. 67.

XIE, J., GUO, Q., ZHU, H., WOOTEN, M.W. and MATTSON, M.P., 2000. Protein kinase $C$ iota protects neural cells against apoptosis induced by amyloid $\beta$-peptide. Brain Research. Molecular Brain Research, vol. 82, no. 1-2, pp. 107-113. http://dx.doi.org/10.1016/ S0169-328X(00)00187-X. PMid:11042363.

YEUNG, F., HOBERG, J.E., RAMSEY, C.S., KELLER, M.D., JONES, D.R., FRYE, R.A. and MAYO, M.W., 2004. Modulation of NFk B-dependent transcription and cell survival by the SIRT1 deacetylase. The EMBO Journal, vol. 23, no. 12, pp. 2369-2380. http://dx.doi.org/10.1038/sj.emboj.7600244. PMid:15152190.

ZHAO, Y.N., LI, W.F., LI, F., ZHANG, Z., DAI, Y.D., XU, A.L., QI, C., GAO, J.M. and GAO, J., 2013. Resveratrol improves learning and memory in normally aged mice through microRNA-CREB pathway. Biochemical and Biophysical Research Communications, vol. 435, no. 4, pp. 597-602. http://dx.doi.org/10.1016/j.bbrc.2013.05.025. PMid:23685142. 